\title{
Gender Matters: The Role of Gender in Human and Machine Communication
}

\author{
Toplumsal Cinsiyet Konusunun İnsan ve Makine İletişimi Bağlamındaki Rolü
}

Öz

Makineler de dahil olmak üzere teknoloji hayatımızı şekillendiren güçlerden biridir. Örnek olarak, tüm müşteri etkileşimlerinin 2025 yılına kadar Yapay Zeka (AI) tarafindan yönlendirilmesi beklenmektedir. Kadın ve teknoloji arasındaki ilişki karmaşıktır ve makine ve cinsiyet söylemi çerçevesinde birden fazla yönü vardır. Öncelikle, toplumsal cinsiyet ilişkileri teknolojiyi bilgilendirir ve şekillendirir, çünkü toplumda egemen olan cinsiyete dayalı varsayımlar ve normlar teknolojinin tasarımın, gelişimini ve üretimini etkiler. İkinci olarak, kadınların Fen, Teknoloji, Mühendislik ve Matematik (STEM) alanlarinda yeterince temsil edilmemeleri ve teknolojinin erkekler tarafindan şekillendirilmesi ve kontrol edilmesi doğrudan sonuçlar doğurmaktadır. Bu makalede, toplumsal cinsiyetin teknolojik üretimin ayrılmaz bir parçasını oluşturduğu ve dikkat gerektirdiği savunulmaktadır. Bu nedenle, makineleri de içerecek şekilde, toplumsal cinsiyet ve teknoloji arasındaki bağlantı bu konudaki tartışmalara entegre edilmelidir. Bu makalede amacım, bu etkileşimleri tartışmak ve makine ve toplumsal cinsiyet söyleminin yıllar içinde nasıl geliştiği hakkında genel bir bakış açısı sağlamaktır. Böylece, makine ve toplumsal cinsiyet bağlantısının Türkiye' de daha iyi anlaşılmasına katkıda bulunmayı hedeflemekteyim.

\section{Abstract}

Technology, including machines, is one of the forces that shapes our lives. As an example, all customer interactions are expected to be driven by Artificial Intelligence (AI) by 2025. The relationship between women and technology is complex and there are multiple aspects within the framework of machine and gender discourse. Firstly, gender relations inform and shape technology since gendered assumptions and norms dominated in society impact the design, development and production of technology. Secondly, women's underrepresentation in Science, Technology, Engineering and Mathematics (STEM) fields have direct consequences since technology seems to be dominated by men. I argue that gender constitutes an integral part of technological production and requires attention. For this reason, the interlinkages between gender and technology should be integrated in discussions including machines. In this paper, my goal is to discuss these interlinkages and provide an overview on how machine and gender discourse have developed over the years. I aim to contribute to a greater understanding of machine and gender discourse in Turkey.

\section{Introduction}

Technology ${ }^{1}$, including machines, are one of the forces that shape our lives. All customer interactions are expected to be driven by Artificial Intelligence (AI) by 2025. I believe that the discussions including human machine communication and artificial intelligence are not complete if we do not include gender perspective, because gender is an integral part of research since 1970 s. Thus, we need to consider gender dynamics if we want to build knowledge. This paper aims to achieve two goals: to highlight the gender dimensions in human and technology/machine discourse to heighten awareness for gender perspective and to provide a short summary on

\footnotetext{
${ }^{1}$ In this paper the term technology consists of the physical including machines, products as well as the skills, knowledge preceding machines and products that are produced and used (Carroll, 2017). Therefore, technology includes machines as well as electronic and information technology amongst others Artificial Intelligence (AI) and the skills and knowledge to use these tools (see Carroll, 2017) for different definitions of technology).
}

\begin{abstract}
Rakibe Külcür
rakibe.kulcur@sustaila.com

Orcid No: https://orcid.org/0000-0003-1874-
\end{abstract}

Article Type / Makale Türü

Anahtar Kelimeler

Makine, teknoloji, toplumsal cinsiyet, yapay

Keywords

Machine, technology, gender, artificial

JEL Codes: $F, M, O$

Submitted: $\quad 11 / 10 / 2021$

Accepted: $\quad 26 / 01 / 2022$ 
technology/machine - gender discourse because the academic discussions including 'technology and gender' and 'machine and gender interaction' are very limited in Turkey.

The interlinkages between women and technology are complex and there are multiple aspects within the framework of machine and gender discourse. As put nicely by Wajcman (2010) technology is a source, but also the result of gender relations. Firstly, gender relations inform and shape technology since gendered assumptions and norms dominated in society impact the design, development and production of technology. As an example, 'gender stereotypes and sexist images are used to build 'better' machines that are perceived as socially intelligent' (Weber, 2005: 214) such as female robots as caregivers (gender stereotypical social relations). Moreover, through digital technologies and AI, social dynamics could be reproduced or existing norms can be reinforced. Secondly, women's lower share of employment in Science, Technology, Engineering and Mathematics (STEM) and Information and Communication Technology (ICT) fields has direct consequences, because this way technology seems to be dominated by men (OECD, 2019).

Although, achieving gender equality ${ }^{2}$ is one of the important goals in many countries, particularly in economically advanced countries, gender parity is not expected to be attained for another 100 years (WEF, 2019). In order to achieve a better and more sustainable future, as formulated in the United Nations' (UN) 2030 Agenda for Sustainable Development, it is important to understand 'gender as an organising principle in all systems including work, politics, economic development, law and other systems' (Coltrane, 2000: ix) and take 'gender as central in constructing all social relations and taking individual women's lives as a problematic and reveal women's everyday world and explore what happens and how events are experienced by women' (Acker, Barry \& Esseveld, 1983: 424).

Machines are often associated with men as a result of the historical and cultural gender construction (duality) as well as men's dominance in the job segments that create and construct technology including machines. It is because privileged elite men dominated mechanical and civil engineering roles during the late 19th century, who defined what technology is (Wajcman, 2010).

The World Health Organization (WHO) (2020) defines gender as the characteristics of women, men, girls and boys that are socially constructed and includes norms, behaviours and roles associated with being a woman, man, girl or boy, as well as relationships with each other. Gender is embedded in everyday interaction and similar to Artificial Intelligence (AI), gender is learned and imitated behaviour that come to process extremely good that it looks natural (Halberstam, 1991). The UNESCO (2019) issued the first recommendation to combat gender bias in applications using artificial intelligence, where it is stressed that it is important to assess technologies to find out whether they are gendered, how they are gendered and who is gendering them.

The following section will provide the methodology, followed by the section on women's representation in the STEM and ICT job segments and an overview on the development of machine and gender discourse.

\section{Methodology}

This paper is designed to explore gender and technology discourse and as such it aims to contribute to feminist discussions on technology and machines in Turkey since there is limited studies and literature on this subject in the country. I use a feminist lens to analyse human and machine interaction by integrating gender perspective into the discussion. In feminist research feminist epistemology is an important issue. Feminist epistemology denounces traditional epistemologies since women are excluded as knowledge agents and science has been dominated by men and masculinity (Harding, 1987).

In order to review the development of machine and gender discourse, I used literature review as a methodology. I utilised several sources including Google Scholar and Web of Science to find the

\footnotetext{
${ }^{2}$ Gender equality includes issues such as 'equal opportunities and treatment in employment; equal remuneration for work of equal value; equality in obtaining meaningful career development; equal access to a safe and healthy working environment and to social security; balance between work and home life that is fair to both gender; sexual harassment' (ILO, 2005: 2).

${ }^{3}$ One of which goals is to achieve gender equality.
} 
potential works to review on machine and gender discourse in English, Turkish and German. A literature search, using certain key words including 'gender and machine'; 'gender and technology', and 'technofeminism' has been conducted. Based on the literature that I identified based on the key words, the references sections of the articles found were checked in order to find more articles. This search identified a lack of any analyses of gender and machine discourse in Turkey.

In addition, I also used several sources of information including the Organisation for Economic Co-operation and Development (OECD), International Labour Organization (ILO), the statistical office of the European Union (EuroStat) and Turkish Statistical Institute (TurkStat) to collect data on the gender representation in the STEM and ICT positions.

\section{Underrepresentation of women in technology development}

In order to monitor the progress on gender equality, it is important to collect and track gender data (ILO, 2020). Although female participation in professional job segments has slowly increased in recent years, women are still not equally represented in many sectors. The employment rate of women in Turkey is very low (31,7\% in comparison to the European Union (EU) average of $66.5 \%)$ and the percentage of women employed in non-agricultural sector is only 19.8\% (Eurostat, 2018; TUIK, 2020). It is known that representational inequality give rise to bias because matters that impact women differently are not represented adequately (Reed \& Mitchell, 2003) and 'without the full and equal participation of half the population, communities and societies will never reach their potential or achieve the 2030 Agenda for Sustainable Development' (International Telecommunication Union, 2019).

The exclusion of women from technological sphere is an outcome of deep-rooted patriarchy. The first machines were designed specifically for female workers (Jarrige, 2013), but women were excluded in the design and manufacture of technology during and after the first Industrial Revolution as a result of the male domination in engineering roles (Cockburn, 1983; Bradley, 1989). Women were only allowed to be admitted to engineering in the 20th century. Similarly, men's domination in science is linked to patriarchy, which is the domination of men in social structures and exclusion of women particularly from powerful positions (socialization, gender division of labour and discrimination). This bias appears to be even invisible to men (Bowling \& Martin, 1985). As a result of this domination in elite positions, scientific knowledge is masculine and neglects women's knowledge and experiences. It is built on hierarchy and competition (Bowling \& Martin, 1985). Consequently, hierarchical gender structures are created at work where men still have more likely to have more status and higher remuneration than women.

Although equal rights movement (women's emancipation) advanced women and women's representation in male dominated occupations and there are initiatives that aim to improve the representation of women and girls in the Information and Communication Technology (ICT) sector such as EQUALS4, women are still under-represented in the fields of STEM and ICT (Charlesworth \& Banaji, 2019). As an example, globally almost $80 \%$ of Artificial Intelligence (AI) professionals are male and only $28 \%$ of women can rise to managerial positions where they can influence decisions (WEF, 2019). Similarly, even in advanced economic countries such as the EU5, men have disproportionate share in high and medium-high technology manufacturing ( $83 \%$ of engineers and scientists in manufacturing are male) (Eurostat, 2019).

It has been demonstrated that gender norms and systems play an important role in differential representation of men and women in certain occupations such as the perception of the stereotypical scientist including in Turkey, who is illustrated in many textbooks as a white male (association of masculinity and technology) (Faulkner, 2001; Good, Woodzicka, \& Wingfield, 2010; Laçin-Şimşek, 2011). It has been found that having a positive attitude toward science has a positive impact on

\footnotetext{
${ }^{4}$ A collaboration between the International Telecommunication Union and UN Women to increase the number of women in the ICT roles.

${ }^{5}$ However, there are some paradoxical findings regarding the gender equality performance of a country and women's representation in the STEM field, namely countries with gender-conservative policies seem to have more women in STEM professions (e.g. certain Arap countries and Turkey) (ITU, 2019).
} 
students' science achievement score (Geesa, Izci, Chen, and Song, 2020) and if girls cannot identify themselves with this prototypical image, they would be less likely to aspire to become one (Gauthier, Hill, McQuillan, Spiegel \& Diamond, 2017). The research also showed that women working in atypical female employment sectors are either overqualified or they are less rewarded than men (Gedikli, 2020).

\section{Machine and gender discourse}

Gender ${ }^{6}$ is defined as socially constructed roles, cultural phenomena and identities (Acker, 1992; Butler, 2011). It 'represents a basic, systematic, constitutive and discursively (re)produced notion' (Bendl, 2008: 50). Scott (1986: 1067) argues that 'gender is a primary way of signifying relationship of power'. Therefore, the construction of gender (the concept of doing gender) emerges from collective and individual acts and as a social construct (West \& Zimmerman, 1987). The perception and definition of gender varies from one society to another society and can change over time and place. Hence, the definitions of maleness and femaleness vary in different countries. For this reason, both technology and gender are seen as 'socially shaped and potentially re-shapeable' (Faulkner, 2001).

Feminist scholars like Harding (1986) demonstrated the binary oppositions embedded in Western culture. According to the Western conception of the world order dualisms are such as man/woman; mind/body; reason/emotion; culture/nature; thought/matter; activity/passivity; human/animal. These oppositions produced the perception of 'defining male as being opposed to and superior to female, and rationality as being opposed to and superior to nature, matter and emotion' (Nelson, 1997: 157). As a result while 'woman, nature and machine are considered as 'other' (Halberstamm, 1991: 444), technical is considered as masculine and non-technical is as feminine.

The discourse on human and machine communication is accepted to be started in the 1700s with the account of Descartes7 (Descartes \& Cress, 1998) who argued that animals were only animated machines (the thesis of animals as automata) (Deuber-Mankowsky, 2019). He believed in distinction between the animal-machine and the soul of reason. According to him, men create machines in the same way as God created the world. Descartes argued that machines act from the disposition of their organs (parts) and humans from universal reasoning. However, he remained silent on where women stand in this duality.

As of 1970s, feminist researchers have analysed men's dominancy on technology. It has been argued that western patriarchy including the masculine science and technology is the root cause of objectification as well as domination over women and nature (Griffin, 1978; Merchant, 1996; Shiva, 2010). The analyses included women's access to technology, but over time there has been a shift to explore the processes that develop and use technology since it was seen that concentrating on only 'access' and ignoring 'design and development' (questioning how technology is produced) meant that technology itself was accepted as 'objective and neutral' and this approach would fail to see important dimensions in production of technology (Henwood, 2000).

Socialist and radical feminists have analysed the gendered nature of technical expertise and the social factors that shape technologies, particularly in relation to inequalities and gender divisions. However, while socialist scholars concentrated on the relation between technology and women's work, radical feminists focused on women's body. Socialist feminists see masculinity in machinery and technology and according to them, these are one of the sources of male power (Cockburn, 2009; Wajcman, 2010) since technology is shaped and dominated by men. On the other hand, liberal feminist scholars looked at this issue as a 'male domination of technology' and aimed to increase the number of women in technology while radical feminists highlighted 'gender power issues in technology and science' and tried to understand the reasons behind the male domination. They highlighted that the idea of 'gender-free' science and technology assumption is bias, because there

${ }^{6}$ I also acknowledge that in addition to gender, other social relations such as race, class and ethnicity are important.

${ }^{7}$ He has been accepted as the father of modern philosophy. 
is no such a thing as gender-neutrality. These views emphasized that technological change would heighten gender hierarchies.

In contrary, as of the 1990s, post-feminist scholars (third-wave feminism) have focused on diversity among women and additional axes of power including race, class, colonialism, sexuality, disability and age (Kirkup, Hovenden, Janes, \& Woodward, 2000; Evans, 2014; Banet-Weiser, Gill, \& Rottenberg, 2020) and they have been optimistic about techno-women relations. As an example, Haraway (1997) suggested a humankind hybridized Cyborg (fused human-machines) as an imaginary figure and as a lived experience that played an important role in the machine and gender discourse. Haraway's 'female cyborg idea' created a 'postmodern identity', which assumes 'otherness and difference'. Haraway's (1997) theory on power of technology and science contributed to empowerment of women since she suggested that gender relations of technoscience could be altered and a new world can be created by developing new meanings. Therefore, Haraway has transformed the relations between women and technology paving the way for new possibilities to explore the intertwined relations between women and technology rather than seeing women as victims of technology (Wajcman, 2010).

Contemporary feminist scholars of science and technology studies have been accepting a social constructivist feminist framework, which see 'gender relations and technology' as a mutual shaping relation as articulated by Wajcman (2010: 143) as 'gender relations can be thought of as materialised in technology, and masculinity and femininity in turn acquire their meaning and character through their enrolment and embeddedness in working machines, therefore the gendering of technology influences the entire life trajectory of an artefact'. Thus, the technology as a notion is accepted as a sociotechnical product, which is a network that combines different elements such as knowledge, people and organisations (Hackett, Amsterdamska, Lynch, \& Wajcman, 2008; Wajcman, 2010; Mohideen, 2020). As a consequence, technology cannot be seen as a separate from society because gender relations influence the production of technology. I agree with Cockburn (1985) and Wajcman $(2007,2010)$ who argued that there exists a fluid two-way relationship between technology and gender where technology is a source, but at the same time a consequence of gender relations and vice versa. Current discussions on gender and technology and technofeminist analyses mostly include digital technologies and $\mathrm{AI}$ such as machine learning and machine translation.

\section{Machine and gender discourse in Turkey}

Although it has been increasingly accepted that technology and technological products are influenced and be influenced by gender identities and interests (technology - gender interaction) and technology/machine and gender discourse have begun to be well established in academic research, in the Turkish academic discussions feminist analyses of technology seem to be very limited. Few exceptions include (Kaygan, 2014; Güdüm, 2015; Özümcan and Kaygan, 2015), Güdüm (2015) who identified the lack of Turkish articles on the subject and highlighted women's influence on technology and new media seven years ago. Özümcan and Kaygan (2015) emphasized that how domestic technologies are designed to target female customers, which is likely to cause domestic abuse through the increased unpaid domestic work by women.

\section{Conclusions}

In this paper, I aim to include feminist perspectives into the discussions including human and machine interaction. I believe that gender and technology are co-produced. Gender constitutes an integral part of technological production and technology produces new meanings and new entities to affect the gender relations. Representation is an important issue since increasing the number of women in male-dominated job segments such as engineering, science and ICT roles will grant women to be part of the design and development process of technology that shape our lives. However, following the constructivist approach, I think that we also need to question technology as a notion because it is designed and produced by people, organisations and knowledge which is produced in society. Consequently, the relationship between gender and technology is a complex intertwining which influence each other, and technology can produce and sustain power issues and 
the women's unequal position in society. Therefore, I think that not considering a gender perspective in discussions concerning technology and machines would lead to bias in research.

\section{References}

Acker, J. (1992). From sex roles to gendered institutions. Contemporary Sociology, 21(5), 565-569.

Acker, J., Barry, K., \& Esseveld, J. (1983). Objectivity and truth: Problems in doing feminist research. In Women's Studies International Forum (Vol. 6: 423-435). Elsevier.

Banet-Weiser, S., Gill, R., \& Rottenberg, C. (2020). Postfeminism, popular feminism and neoliberal feminism? Sarah Banet-Weiser, Rosalind Gill and Catherine Rottenberg in conversation. Feminist Theory, 21(1), 3-24.

Bendl, R. (2008). Gender Subtexts - Reproduction of Exclusion in Organizational Discourse*. British Journal of Management, 19(s1), S50-S64. https://doi.org/10.1111/j.1467-8551.2008.00571.x

Bowling, J., \& Martin, B. (1985). Science: a masculine disorder? Science and Public Policy, 12(6), 308316. https:// doi.org/10.1093/spp/12.6.308

Bradley, H. (1989). Men's Work, Women's Work. Cambridge: Polity Press.

Butler, J. (2011). Bodies That Matter: On the Discursive Limits of Sex. Taylor \& Francis. Retrieved from https:/ / books.google.at/books?id=UczySqq19AIC

Carroll, L. S. L. (2017). A comprehensive definition of technology from an ethological perspective. Social Sciences, 6(4), 126.

Charlesworth, T. E. S., \& Banaji, M. R. (2019). Gender in Science, Technology, Engineering, and Mathematics: Issues, Causes, Solutions. The Journal of Neuroscience, 39(37), 7228 LP - 7243. https://doi.org/10.1523/JNEUROSCI.0475-18.2019

Cockburn, C. (1983). Brothers: Male Dominance and Technological Change. London: Pluto Press.

Cockburn, C. (1985). Machinery of Dominance: Women, Men and Technical Know-How. London: Pluto Press.

Cockburn, C. (2009). On" The Machinery of Dominance: Women, Men, and Technical Know-How". Women's Studies Quarterly, 37(1/2), 269-273.

Coltrane, S. (2000). The gender lens: Gender and families,. Oxford: AltaMira Press.

Descartes, R., \& Cress, D. A. (1998). Discourse on Method (Third Edition). Hackett Publishing Company. Retrieved from https:/ / books.google.at/books?id=URMSbDE9JvgC

Deuber-Mankowsky A. (2019). Mensch-Maschine- Interaktion. Handbuch zu Geschichte, Kultur, Ethik. In K. Liggieri \& O. Müller (Eds.) (p. 381). J.B. Metzler. Retrieved from https:/ / books.google.at/books?id=n7yxDwAAQBAJ

Eurostat. (2018). Women's employment in the EU. Retrieved from https:/ / ec.europa.eu/ eurostat/web/products-eurostat-news/-/EDN-20200306-1

Eurostat. (2019). Women in science and technology.

Evans, E. (2014). The politics of third wave feminisms. Springer.

Faulkner, W. (2001). The technology question in feminism: A view from feminist technology studies. Women's Studies International Forum, 24(1), 79-95. https:// doi.org/https://doi.org/10.1016/S0277-5395(00)00166-7

Gauthier, G. R., Hill, P. W., McQuillan, J., Spiegel, A. N., \& Diamond, J. (2017). The potential scientist's dilemma: How the masculine framing of science shapes friendships and science job aspirations. Social Sciences, 6(1), 14.

Gedikli, C. (2020). Occupational Gender Segregation in Turkey: The Vertical and Horizontal Dimensions. Journal of Family and Economic Issues, 41, 121-139.

Geesa, R., Izci, B., Chen, S., S. H. (2020). The role of gender and attitudes toward science in fourth and eighth graders' science achievement in South Korea, Turkey, and the United States. Journal of Research in Education, 29(2), 54-86.

Good, J. J., Woodzicka, J. A., \& Wingfield, L. C. (2010). The Effects of Gender Stereotypic and Counter-Stereotypic Textbook Images on Science Performance. The Journal of Social Psychology, 150(2), 132-147. https://doi.org/10.1080/00224540903366552

Griffin, S. (1978). Woman and Nature: The Roaring Inside Her. New York: Harper and Row. 
Güdüm, S. (2015). Women in Technology: Google Women Tech-Makers Case (pp. 979-985). METU, Studies, nternational Conference on Knowledge and Politics in Gender and Women's.

Hackett, E. J., Amsterdamska, O., Lynch, M., \& Wajcman, J. (2008). The handbook of science and technology studies. MIT Press.

Halberstam, J. (1991). Automating Gender: Postmodern Feminism in the Age of the Intelligent Machine. Feminist Studies, 17(3), 439-460. https:/ / doi.org/10.2307/3178281

Haraway, D. J. (1997). The virtual speculum in the new world order. Feminist Review, 55(1), 22-72.

Harding, S. (1986). The science question in feminism. Ithaca: Cornell University.

Harding, S. (1987). Is there a feminist method? Feminism and Methodology. Social Sciences Issues. Indiana University Press.

Henwood, F. (2000). From the woman question in technology to the technology question in feminism: Rethinking gender equality in IT education. European Journal of Women's Studies, $7(2), 209-227$.

ILO. (2005). Employers' Organizations taking the lead on Gender Equality: Case studies from 10 countries.

ITU. (2019). Taking Stock: Data and evidence on gender equality. Retrieved from https://www.itu.int/en/action/gender-equality/Documents/EQUALS Research Report 2019.pdf

Jarrige, F. (2013). Gender and machine-breaking: violence and mechanization at the dawn of the industrial age (England and France 1750-1850). Clio [Online], 38. Retrieved from http://journals.openedition.org/cliowgh/284

Kaygan, P. (2014). 'Arty' versus 'Real' Work: Gendered Relations between Industrial Designers and Engineers in Interdisciplinary Work Settings. The Design Journal, 17(1), 73-90. https://doi.org/10.2752/175630614X13787503069990

Kirkup, G., Hovenden, F., Janes, L., \& Woodward, K. (2000). The Gendered Cyborg: A Reader. Routledge. Retrieved from https://books.google.at/books?id=UgU1TEyU4JUC

Laçin-Şimşek, C. (2011). Women scientist in science and technology textbooks in turkey. Journal of Baltic Science Education, 10(4), 277-284.

Merchant, C. (1996). Earthcare: Women and the environment. New York: Routledge.

Mohideen, R. (2020). Gender-Powered Approaches. In Women and the Energy Revolution in Asia (pp. 9-26). Springer.

Nelson, J. A. (1997). Feminism, ecology and the philosophy of economics. Ecological Economics, 20(2), 155-162.

OECD. (2019). Women at Work in G20 countries: Progress and policy action. Retrieved from https://www.oecd.org/g20/summits/osaka/G20-Women-at-Work.pdf

Özümcan, Demira and Kaygan, P. (2015). Fountain Pens: Gender Asymmetries in Managerial Careers. In nternational Conference on Knowledge and Politics in Gender and Women's Studies (pp. 848-857). METU, Studies, nternational Conference on Knowledge and Politics in Gender and Women's.

Reed, M. G., \& Mitchell, B. (2003). Gendering environmental geography. The Canadian Geographer / Le Géographe Canadien, 47(3), 318-337. https:/ / doi.org/10.1111/1541-0064.00025

Scott, J. W. (1986). Gender: A Useful Category of Historical Analysis. The American Historical Review, 91(5), 1053-1075.

Shiva, V. (2010). Women, Ecology and Survival in India. Spinifex Press. North Melbourne.

TUIK. (2020). Labour Force Statistics, July 2020. Retrieved from https:/ / data.tuik.gov.tr/en/display-bulletin/?bulletin=labour-force-statistics-july-2020-33791

UNESCO. (2019). First UNESCO recommendations to combat gender bias in applications using artificial intelligence. Retrieved from https://en.unesco.org/news/first-unescorecommendations-combat-gender-bias-applications-using-artificial-intelligence

Wajcman, J. (2007). From women and technology to gendered technoscience. Information, Communication \& Society, 10(3), 287-298. https:/ / doi.org/10.1080/13691180701409770 
Wajcman, J. (2010). Feminist theories of technology. Cambridge Journal of Economics, 34(1), 143152. https:// doi.org/10.1093/cje/ben057

Weber, J. (2005). Helpless machines and true loving care givers: a feminist critique of recent trends in human-robot interaction. Journal of Information, Communication and Ethics in Society.

WEF. (2019). Global Gender Gap Report 2020: Insight Report. Retrieved from http://www3.weforum.org/docs/WEF_GGGR_2020.pdf

West, C., \& Zimmerman, D. H. (1987). Doing Gender. Gender \& Society, 1(2), 125-151. https:/ / doi.org/10.1177/0891243287001002002

WHO. (2020). Gender and health. Retrieved from https://www.who.int/health-topics/gender 